\title{
Página da Direção
}

\section{Novos desafios}

A criação do Grupo de Estudos do Cancro do Pulmão (GECP) pretendeu, na sua génese, juntar esforços na promoção do conhecimento em Oncologia Torácica, nas suas múltiplas vertentes.

Recentemente, com a alteração dos seus estatutos, evoluiu para IPSS. Foi então possível alcançar um enquadramento mais amplo e de maior proximidade à população. Esta via possibilitou a concretização de inúmeras acções dirigidas a uma audiência mais vasta no contexto da oncologia pulmonar.

A vaga pandémica que se instalou em 2020 veio colocar novos desafios, pondo à prova os métodos e testando a capacidade de mantermos intactos os nossos objectivos.

Recorrendo de forma sistemática aos canais telemáticos de comunicação, foi possível manter os projectos em curso na área investigacional e concretizar algumas das habituais reuniões do GECP. Apesar de terem ocorrido num formato diferente, originaram seguramente novos desafios a todos os interlocutores.

A concretização do $9 .^{\circ}$ Congresso Português do Grupo de Estudos do Cancro do Pulmão no passado mês de outubro de 2021 que decorreu maioritariamente sob a forma presencial foi sem dúvida um dos pontos altos desse ano.

Dentro desta perspectiva de mudança, alterámos o logotipo do GECP.

Lançámos ainda um novo desafio, o de evoluirmos para a concretização do $1{ }^{\circ}$ Congresso Português do Cancro do Pulmão, previsto para este ano. Trata-se sem dúvida de uma tarefa complexa tendo em conta as incertezas que ainda subsistem no contexto pandémico actual.

Fica a confiança de que, embora se mantenham as incertezas, estamos perante uma nova geração de especialistas dedicados e atentos à evolução da abordagem multidisciplinar do cancro do pulmão. A sua entrada no GECP permite-nos encarar com tranquilidade a evolução dos projectos lançados e constituir novas bases de entendimento e inovação para plataformas futuras de colaboração no âmbito deste grupo.

Paulo Costa

Janeiro 2022 